\title{
The protective effect of $\beta$-carotene on genotoxicity induced by cyclophosphamide
}

\author{
Daisy M.F. Salvadori ${ }^{1}$, Lúcia R. Ribeiro ${ }^{1}$, Marília D.M. Oliveira ${ }^{1}$, \\ Carlos A.B. Pereira ${ }^{2}$ and Willy Beçak ${ }^{3}$ \\ ${ }^{1}$ Laboratório de Toxicologia e Genética Toxicológica, Escola de Medicina Veterinária, Universidade Federal da Bahia, Ondina, 40210, \\ Salvador-BA, ${ }^{2}$ Departamento de Estatística, Instituto de Matemática e Estatística, Universidade de São Paulo, São Paulo-SP and \\ ${ }^{3}$ Serviço de Genética, Instituto Butantan, Säo Paulo-SP (Brazil)
}

(Received 19 August 1991)

(Accepted 22 August 1991)

Keywords: Antimutagenesis; $\beta$-Carotene; Chromosome aberration; Cyclophosphamide

\section{Summary}

The influence of $\beta$-carotene on the clastogenicity of the indirect-acting mutagen cyclophosphamide (CPA) was investigated in mice, in vivo, for the induction of chromosome aberrations in bone marrow cells (BM). $\beta$-Carotene $(0.5,1.0,2.0,5.0,10,25,50,100$ and $200 \mathrm{mg} / \mathrm{kg})$ was administered by gavage for 5 consecutive days. $4 \mathrm{~h}$ after the last treatment with $\beta$-carotene, the mice were injected intraperitoneally with CPA, and the BM cells were fixed after 16, 24 and $32 \mathrm{~h}$ for the evaluation of the frequency of chromosome aberrations. The results showed that $\beta$-carotene was effective in reducing chromosomal damage induced by CPA with the increase of its concentration up to a level after which this effect was not observed. This anticlastogenicity was better detected when the cells were fixed at $32 \mathrm{~h}$, although a tendency in reducing the CPA clastogenicity was already observed at 16 and $24 \mathrm{~h}$. Our results suggest that $\beta$-carotene provides significant protection against the genotoxicity of CPA, although no dose-effect relationship on the frequencies of cells with chromosomal aberrations was observed.

The fact that mutagenic events seem to be of critical importance in carcinogenicity suggests that certain human cancers might be prevented by identification of mutagens in the environment. However, many experiments are currently underway in order to detect agents which can suppress cellular mutagenesis and carcinogenesis. During

Correspondence: Dr. Daisy M.F. Salvadori, Laboratório de Toxicologia e Genética Toxicológica, Escola de Medicina Veterinária, Universidade Federal da Bahia, Ondina, 40210, Salvador-BA (Brazil). the past decade, a large number of compounds which can inhibit the development of cancer has been identified. Many of these compounds are found to occur naturally in food or elsewhere in nature.

$\beta$-Carotene, an important provitamin A, widely distributed in dark green leaf vegetables, carrot, and certain red and yellow fruits, has been used as a protective agent against mutagenesis. Several epidemiological studies have indicated that an increased intake of foods rich in carotenoids is related to a reduced incidence of various types of 
cancer (Peto et al., 1981; Moon and Itri, 1984; Wald, 1987; Ziegler, 1989).

Some studies have suggested that $\beta$-carotene has an inhibitory effect on the genotoxic activity of several compounds. Raj and Katz (1985), using benzo[ $a]$ pyrene and mitomycin $\mathrm{C}$, reported a positive anticlastogenic activity of $\beta$-carotene in mouse bone marrow cells for induction of chromosome breaks. Abraham et al. (1986) showed that carrot juice has an inhibitory effect on the induction of chromosome damage detected as micronuclei, induced by cyclophosphamide (CPA), in mouse bone marrow cells. Darroudi et al. (1988) reported a reduction in the frequencies of sister chromatid exchanges in human lymphocytes and in Chinese hamster ovary ( $\mathrm{CHO}$ ) cells treated with plasma containing CPA metabolites, from rats, which had been given carrot juice or water for a week before treatment with CPA. In tissue culture systems (Manoharan and Banerjee, 1985; Stich and Dunn, 1986) and in Salmonella typhimurium (Belisario et al., 1985), $\beta$-carotene was found to exert a protective effect against the mutagenic and clastogenic action of some, but not all, genotoxic agents tested.

The mechanisms of the protective action of $\beta$-carotene are not well understood. It has been suggested that $\beta$-carotene may act as an antioxidant functioning as an effective radical-trapping agent (Burton and Ingold, 1984) and remarkably efficient quencher of singlet oxygen (Krinsky and Deneke, 1982). The possibility that $\beta$-carotene exerts its antimutagenic effect by affecting the processes of enzymatic activation of promutagens/carcinogens was also suggested by Darroudi et al. (1988) and by De Flora (1990).

In the present study, we have investigated whether $\beta$-carotene acts as an anticlastogenic agent modulating the frequency of chromosomal aberrations induced in vivo by cyclophosphamide, an agent which is commonly used as a chemotherapeutic drug and is a well-known indirectly acting mutagen and clastogen (Mohn and Ellenberger, 1976).

\section{Material and methods}

The experiments were performed with $8-10$ week old Balb C male mice (25-35 g) obtained from our own colony, maintained at $25^{\circ} \mathrm{C}$ and receiving food and water ad libitum.

$\beta$-Carotene ( $\beta$-carotene $10 \%$ WS, Roche, Brazil) dissolved in bidistilled water until desired concentrations $(0.5,1.0,2.0,5.0,10,25,50,100$ and $200 \mathrm{mg} / \mathrm{kg}$ ), was administered by gavage $(0.05 \mathrm{ml} / 10 \mathrm{~g} \mathrm{~b}$.w. $)$ for 5 consecutive days. Cyclophosphamide (Enduxan, Pravaz), $20 \mathrm{mg} / \mathrm{kg}$, dissolved in bidistilled water, was injected intraperitoneally $4 \mathrm{~h}$ after the last treatment with $\beta$-carotene. Mice were divided into 12 groups. The negative control group received just water $(0.05 \mathrm{ml} / 10 \mathrm{~g} \mathrm{b.w}$.) by gavage. The control group received water for 5 consecutive days, plus CPA 4 $\mathrm{h}$ after the last treatment. 1 group was given only the highest concentration of $\beta$-carotene ( 200 $\mathrm{mg} / \mathrm{kg}$ ). The other 9 groups received 9 different concentrations of $\beta$-carotene plus CPA. Each group consisted of 10 animals.

Groups of treated animals were killed by cervical dislocation 16, 24 and $32 \mathrm{~h}$ after the treatment with CPA and the evaluation of chromosome aberration frequencies was carried out using conventional techniques (Hsu and Patton, 1969).

The slides were stained in $10 \%$ aqueous Giemsa solution and 100 bone marrow metaphase cells from each animal were scored under code. The types of chromosomal aberrations considered were: chromatid and chromosome gaps, breaks and fragments, exchanges and pulverization (severely damaged cells). The reduction factor due to $\beta$-carotene treatment was calculated using the formula:

$\%$ reduction $=\frac{\left(\begin{array}{c}\text { aberrant cells } \\ \text { in control }\end{array}-\begin{array}{c}\text { aberrant cells in } \\ \mathrm{CPA}+\beta \text {-carotene }\end{array}\right)}{\left(\begin{array}{c}\text { aberrant cells } \\ \text { in control }\end{array}-\begin{array}{c}\text { aberrant cells in } \\ \text { negative control }\end{array}\right)} \times 100$

The data were statistically analysed by the $\chi^{2}$ test, according to Pereira (1991).

\section{Results}

From the results of the present study it was possible to make a comparison of the cytogenetic damage induced by intraperitoneally injected $\mathrm{CPA}$ in mice which had previously received either 
TABLE 1

EFFECT OF $\beta$-CAROTENE ON THE FREQUENCY OF CELLS WITH CHROMOSOME ABERRATIONS INDUCED BY CYCLOPHOSPHAMIDE (CPA $20 \mathrm{mg} / \mathrm{kg}$ )

\begin{tabular}{|c|c|c|c|c|c|c|c|}
\hline \multirow[t]{2}{*}{ Treatment } & \multirow{2}{*}{$\begin{array}{l}\beta \text {-Carotene } \\
(\mathrm{mg} / \mathrm{kg})\end{array}$} & \multicolumn{4}{|c|}{ Types of chromatid aberrations } & \multicolumn{2}{|c|}{ Aberrant cells } \\
\hline & & Gaps & Breaks & Fragments & Exchanges & No. & $(\%)$ \\
\hline$\overline{\text { Water }^{\mathrm{a}}}$ & 0 & 2 & 2 & 22 & 0 & 18 & $\overline{(1.8)}$ \\
\hline $\mathrm{CPA}+$ water $^{\mathrm{b}}$ & 0 & 29 & 12 & 51 & 1 & 76 & (7.6) \\
\hline \multirow[t]{6}{*}{$\mathrm{CPA}+\beta$-carotene } & 5 & 22 & 11 & 83 & 2 & 76 & $(7.6)$ \\
\hline & 10 & 12 & 6 & 77 & 1 & 63 & (6.3) \\
\hline & 25 & 14 & 18 & 58 & 0 & 58 & $(5.8)$ \\
\hline & 50 & 31 & 13 & 72 & 0 & $91^{\mathrm{c}}$ & $(9.1)$ \\
\hline & 100 & 55 & 10 & 45 & 1 & 83 & $(8.3)$ \\
\hline & 200 & 34 & 15 & 50 & 0 & 87 & $(8.7)$ \\
\hline
\end{tabular}

The animals were killed $16 \mathrm{~h}$ after CPA treatment. 1000 cells from 10 animals were analysed for each point.

a Negative control.

${ }^{b}$ Control.

c 2 cells had pulverized chromosomes.

water or $\beta$-carotene. The data presented in Tables 1 and 2 show that supplementation of $\beta$ carotene $(5,10,25,50,100$ and $200 \mathrm{mg} / \mathrm{kg}$ ) before the CPA treatment did not statistically reduce the frequency of aberrant cells (Table 1) or the incidence of structural chromosomal aberrations (Table 2) when the cells were fixed at $16 \mathrm{~h}$ following the CPA treatment, although it has been possible to visualize a tendency of $\beta$-carotene $(10$ and $25 \mathrm{mg} / \mathrm{kg})$ to reduce genotoxicity of CPA.

The data presented in Table 3 show that, when the fixation time was $24 \mathrm{~h}$, the $\beta$-carotene supplementation (10 and $25 \mathrm{mg} / \mathrm{kg})$ was effective in

TABLE 2

EFFECT OF $\beta$-CAROTENE ON THE FREQUENCY OF CHROMOSOME ABERRATIONS INDUCED BY CYCLOPHOSPHAMIDE (CPA $20 \mathrm{mg} / \mathrm{kg}$ )

\begin{tabular}{|c|c|c|c|c|c|c|c|c|c|}
\hline \multirow[t]{2}{*}{ Treatment } & \multirow{2}{*}{$\begin{array}{l}\beta \text {-Carotene } \\
(\mathrm{mg} / \mathrm{kg})\end{array}$} & \multicolumn{7}{|c|}{ Cells with aberrations } & \multirow{2}{*}{$\begin{array}{l}\text { Total number of } \\
\text { aberrations }\end{array}$} \\
\hline & & $\overline{0}$ & 1 & 2 & 3 & 4 & 5 & $\overline{6-9}$ & \\
\hline Water $^{a}$ & 0 & 982 & 11 & 6 & 1 & 0 & 0 & 0 & 26 \\
\hline $\mathrm{CPA}+$ water $^{\mathrm{b}}$ & 0 & 924 & 63 & 10 & 2 & 1 & 0 & 0 & 93 \\
\hline \multirow[t]{6}{*}{$\mathrm{CPA}+\beta$-carotene } & 5 & 924 & 52 & 15 & 5 & 1 & 2 & 1 & 118 \\
\hline & 10 & 937 & 47 & 8 & 3 & 2 & 2 & 1 & 96 \\
\hline & 25 & 942 & 38 & 11 & 7 & 1 & 1 & 0 & 90 \\
\hline & 50 & 909 & 70 & 15 & 2 & 1 & 0 & 1 & 116 \\
\hline & 100 & 917 & 62 & 17 & 1 & 3 & 0 & 0 & 111 \\
\hline & 200 & 913 & 76 & 10 & 1 & 0 & 0 & 0 & 99 \\
\hline
\end{tabular}

The animals were killed $16 \mathrm{~h}$ after CPA treatment. 1000 cells from 10 animals were analysed for each point.

a Negative control.

b Control. 
TABLE 3

EFFECT OF $\beta$-CAROTENE ON THE FREQUENCY OF CELLS WITH CHROMOSOME ABERRATIONS INDUCED BY CYCLOPHOSPHAMIDE (CPA $20 \mathrm{mg} / \mathrm{kg}$ )

\begin{tabular}{|c|c|c|c|c|c|c|c|c|c|}
\hline \multirow[t]{2}{*}{ Treatment } & \multirow{2}{*}{$\begin{array}{l}\beta \text {-Carotene } \\
(\mathrm{mg} / \mathrm{kg})\end{array}$} & \multirow{2}{*}{$\begin{array}{l}\text { Cells with } \\
\text { pulverized } \\
\text { chromosomes }\end{array}$} & \multicolumn{4}{|c|}{ Types of chromatid aberrations } & \multicolumn{2}{|c|}{ Aberrant cells } & \multirow{2}{*}{$\begin{array}{l}\text { Reduction } \\
\text { (\%) }\end{array}$} \\
\hline & & & Gaps & Breaks & Fragments & Exchanges & No. & $(\%)$ & \\
\hline Water $^{a}$ & 0 & 0 & 3 & 1 & 21 & 0 & 20 & $(2.0)$ & - \\
\hline CPA + water ${ }^{b}$ & 0 & 10 & 31 & 17 & 154 & 6 & 131 & $(13.1)$ & - \\
\hline$\beta$-Carotene & 200 & 0 & 2 & 1 & 22 & 0 & 17 & (1.7) & - \\
\hline \multirow[t]{9}{*}{$\mathrm{CPA}+\beta$-carotene } & 0.5 & 2 & 24 & 18 & 156 & 2 & 127 & $(12.7)$ & - \\
\hline & 1.0 & 8 & 37 & 16 & 161 & 5 & 144 & (14.4) & - \\
\hline & 2.0 & 0 & 20 & 13 & 145 & 4 & 124 & $(12.4)$ & - \\
\hline & 5.0 & 1 & 34 & 7 & 177 & 0 & 125 & (12.5) & - \\
\hline & 10 & 3 & 34 & 15 & 148 & 1 & 110 & $(11.0) *$ & 18.9 \\
\hline & 25 & 3 & 15 & 4 & 98 & 0 & 83 & $(8.3) *$ & 43.2 \\
\hline & 50 & 7 & 38 & 14 & 143 & 4 & 132 & (13.2) & - \\
\hline & 100 & 11 & 40 & 17 & 150 & 4 & 142 & $(14.2)$ & - \\
\hline & 200 & 6 & 36 & 12 & 148 & 4 & 132 & $(13.2)$ & - \\
\hline
\end{tabular}

The animals were killed $24 \mathrm{~h}$ after CPA treatment. 1000 cells from 10 animals were analysed for each point.

a Negative control.

b Control.

* Significant at $1 \%$ level $(P<0.01)$.

TABLE 4

EFFECT OF $\beta$-CAROTENE ON THE FREQUENCY OF CHROMOSOME ABERRATIONS INDUCED BY CYCLOPHOSPHAMIDE (CPA $20 \mathrm{mg} / \mathrm{kg}$ )

\begin{tabular}{|c|c|c|c|c|c|c|c|c|c|}
\hline \multirow[t]{2}{*}{ Treatment } & \multirow{2}{*}{$\begin{array}{l}\beta \text {-Carotene } \\
(\mathrm{mg} / \mathrm{kg})\end{array}$} & \multicolumn{7}{|c|}{ Cells with aberrations } & \multirow{2}{*}{$\begin{array}{l}\text { Total number of } \\
\text { aberrations }\end{array}$} \\
\hline & & 0 & 1 & 2 & 3 & 4 & 5 & $6-9$ & \\
\hline Water $^{a}$ & 0 & 980 & 16 & 3 & 1 & 0 & 0 & 0 & 25 \\
\hline $\mathrm{CPA}+$ water $^{\mathrm{b}}$ & 0 & 869 & 81 & 16 & 10 & 8 & 3 & 3 & 208 \\
\hline$\beta$-Carotene & 200 & 983 & 17 & 0 & 0 & 0 & 0 & 0 & 17 \\
\hline \multirow[t]{9}{*}{$\mathrm{CPA}+\beta$-carotene } & 0.5 & 873 & 85 & 19 & 12 & 5 & 3 & 1 & 200 \\
\hline & 1.0 & 856 & 87 & 31 & 8 & 7 & 1 & 2 & 219 \\
\hline & 2.0 & 876 & 90 & 23 & 5 & 4 & 0 & 2 & 182 \\
\hline & 5.0 & 875 & 74 & 25 & 13 & 7 & 3 & 2 & 218 \\
\hline & 10 & 890 & 58 & 29 & 8 & 6 & 3 & 3 & 198 \\
\hline & 25 & 917 & 58 & 16 & 2 & 1 & 2 & 1 & $117 *$ \\
\hline & 50 & 868 & 84 & 24 & 6 & 7 & 3 & 1 & 199 \\
\hline & 100 & 858 & 91 & 21 & 7 & 6 & 4 & 2 & 211 \\
\hline & 200 & 868 & 86 & 23 & 6 & 6 & 4 & 1 & 200 \\
\hline
\end{tabular}

The animals were killed $24 \mathrm{~h}$ after CPA treatment. 1000 cells from 10 animals were analysed for each point.

a Negative control.

b Control.

* Significant at $1 \%$ level $(P<0.01)$. 
TABLE 5

EFFECT OF $\beta$-CAROTENE ON THE FREQUENCY OF CELLS WITH CHROMOSOME ABERRATIONS INDUCED BY CYCLOPHOSPHAMIDE (CPA $20 \mathrm{mg} / \mathrm{kg}$ )

\begin{tabular}{|c|c|c|c|c|c|c|c|c|c|}
\hline \multirow[t]{2}{*}{ Treatment } & \multirow{2}{*}{$\begin{array}{l}\beta \text {-Carotene } \\
(\mathrm{mg} / \mathrm{kg})\end{array}$} & \multirow{2}{*}{$\begin{array}{l}\text { Cells with } \\
\text { pulverized } \\
\text { chromosomes }\end{array}$} & \multicolumn{4}{|c|}{ Types of chromatid aberrations } & \multicolumn{2}{|c|}{ Aberrant cells } & \multirow{2}{*}{$\begin{array}{l}\text { Reduction } \\
(\%)\end{array}$} \\
\hline & & & $\overline{\text { Gaps }}$ & Breaks & Fragments & $\overline{\text { Exchanges }}$ & No. & $(\%)$ & \\
\hline Water $^{\text {a }}$ & 0 & 0 & 4 & 2 & 10 & 1 & 14 & (1.4) & - \\
\hline $\mathrm{CPA}+$ water $^{\mathrm{b}}$ & 0 & 16 & 42 & 15 & 129 & 1 & 107 & $(10.7)$ & - \\
\hline$\beta$-Carotene & 200 & 0 & 3 & 0 & 11 & 0 & 13 & (1.3) & - \\
\hline \multirow[t]{6}{*}{$\mathrm{CPA}+\beta$-carotene } & 5 & 8 & 36 & 13 & 62 & 1 & 74 & $(7.4) *$ & 35.5 \\
\hline & 10 & 9 & 32 & 15 & 66 & 0 & 76 & $(7.6) *$ & 33.3 \\
\hline & 25 & 15 & 44 & 15 & 72 & 2 & 82 & $(8.2)^{*}$ & 26.9 \\
\hline & 50 & 6 & 11 & 8 & 82 & 4 & 66 & $(6.6) *$ & 44.1 \\
\hline & 100 & 12 & 27 & 14 & 124 & 0 & 94 & (9.4) & - \\
\hline & 200 & 26 & 14 & 7 & 74 & 1 & 86 & (8.6) & - \\
\hline
\end{tabular}

The animals were killed $32 \mathrm{~h}$ after CPA treatment. 1000 cells from 10 animals were analysed for each point.

a Negative control.

b Control.

* Significant at $5 \%$ level $(P<0.05)$.

reducing the frequency of aberrant metaphases (18 and $43.2 \%$, respectively). The data presented in Table 4 show a statistically significant decrease in the incidence of structural chromosomal aberrations, when $\beta$-carotene at a dose of $25 \mathrm{mg} / \mathrm{kg}$ was administered.
When the animals were killed $32 \mathrm{~h}$ after treatment with CPA, a greater number of $\beta$-carotene concentrations $(5,10,25$ and $50 \mathrm{mg} / \mathrm{kg})$ were effective in reducing either the frequency of aberrant cells (Table 5) or the incidence of chromosomal aberrations (Table 6). Although $\beta$-carotene

TABLE 6

EFFECT OF $\beta$-CAROTENE ON THE FREQUENCY OF CHROMOSOME ABERRATIONS INDUCED BY CYCLOPHOSPHAMIDE (CPA $20 \mathrm{mg} / \mathrm{kg}$ )

\begin{tabular}{|c|c|c|c|c|c|c|c|c|c|}
\hline \multirow[t]{2}{*}{ Treatment } & \multirow{2}{*}{$\begin{array}{l}\beta \text {-Carotene } \\
(\mathrm{mg} / \mathrm{kg})\end{array}$} & \multicolumn{7}{|c|}{ Cells with aberrations } & \multirow{2}{*}{$\begin{array}{l}\text { Total number of } \\
\text { aberrations }\end{array}$} \\
\hline & & 0 & 1 & 2 & 3 & 4 & 5 & $\overline{6-9}$ & \\
\hline Water $^{\text {a }}$ & 0 & 986 & 12 & 1 & 1 & 0 & $\overline{0}$ & 0 & 17 \\
\hline $\mathrm{CPA}+$ water $^{\mathrm{b}}$ & 0 & 893 & 52 & 17 & 7 & 6 & 4 & 5 & 187 \\
\hline$\beta$-Carotene & 200 & 987 & 12 & 1 & 0 & 0 & 0 & 0 & 14 \\
\hline \multirow[t]{6}{*}{$\mathrm{CPA}+\beta$-carotene } & 5 & 926 & 39 & 18 & 3 & 3 & 2 & 1 & $112^{*}$ \\
\hline & 10 & 924 & 41 & 15 & 5 & 5 & 0 & 1 & $113^{*}$ \\
\hline & 25 & 918 & 39 & 10 & 9 & 2 & 3 & 4 & $133^{*}$ \\
\hline & 50 & 934 & 38 & 11 & 5 & 2 & 3 & 1 & $105^{*}$ \\
\hline & 100 & 906 & 43 & 21 & 7 & 4 & 2 & 5 & 165 \\
\hline & 200 & 914 & 42 & 12 & 0 & 2 & 2 & 2 & $96^{*}$ \\
\hline
\end{tabular}

The animals were killed $32 \mathrm{~h}$ after CPA treatment. 1000 cells from 10 animals were analysed for each point.

a Negative control.

b Control.

* Significant at $1 \%$ level $(P<0.01)$. 


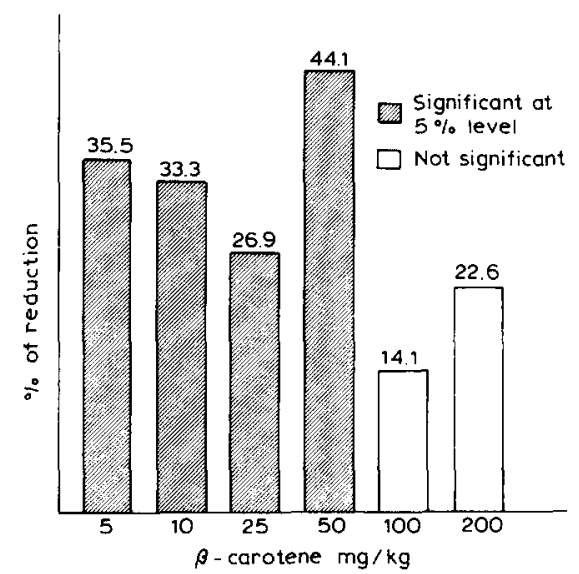

Fig. 1. Percentage of reduction of aberrant cells after treatment with $\mathrm{CPA}+\boldsymbol{\beta}$-carotene (animals were killed $32 \mathrm{~h}$ after CPA treatment).

$(200 \mathrm{mg} / \mathrm{kg})$ did not statistically reduce the frequency of aberrant cells, it was effective in reducing the frequency of chromosome aberrations. Nevertheless, a direct dose-response relationship for the effective concentrations of $\beta$-carotene could not be detected. Fig. 1 shows the activity profile of $\beta$-carotene on CPA clastogenicity at a fixation time of $32 \mathrm{~h}$.

No statistically significant difference in the distribution of aberrations/cell was observed between the groups of animals compared.

\section{Discussion}

The modulation of genotoxicity in somatic cells has provided a tool for improving human health, by extending life expectancy and by preventing mutation-related diseases, such as cancer. A number of dietary components has been identified as inhibitors of mutagenesis and carcinogenesis induced by various chemical mutagens. The present study was therefore aimed at clarifying the hypothesis that $\beta$-carotene protects against chromosomal damage induced by CPA.

Our results show that $\beta$-carotene was effective in reducing chromosomal damage induced by CPA under certain conditions. The anticlastogenic action of $\beta$-carotene occurred with the increase of its concentration up to a certain level after which this effect was not observed. Thus, the higher concentrations tested did not show any protective action.

The mechanism of the anticlastogenic action of $\beta$-carotene is not yet well understood. The existing literature suggests some mechanisms by which this provitamin could act. First, $\beta$-carotene could be acting as a modulator of the metabolism, selectively inhibiting certain forms of mixed-function oxidases that are involved in the metabolism of xenobiotics. Basu et al. (1987) reported the effect of dietary supplements of $\beta$-carotene on hepatic microsomal drug-metabolizing enzyme activities in mice. Their results showed a marked reduction in the hepatic concentration of cytochrome $P-450$, which is one of the enzymatic systems involved in the metabolism of CPA (Domeyer and Sladek, 1980). According to Cohen and Jao (1970), the mixed function oxidase system involved in the CPA metabolism can be inhibited in vitro by compounds known also to be metabolized by the same enzymatic system. Such an inhibition is of a competitive type. Thus, as $\beta$-carotene also requires cytochrome $P$-450-dependent enzymes to be converted into vitamin $A$, the protective effect of $\beta$-carotene may be due to a competitive inhibition of this enzymatic system, thus decreasing the metabolic activation of CPA.

Abraham et al. (1986) and Darroudi et al. (1988) reported that carrot juice, and probably $\beta$-carotene, have an inhibitory effect on the genotoxic activity of CPA, possibly by interfering with the enzymatic processes of its activation. It is known that CPA is an indirect-acting agent which needs previous activation to be mutagenic. So, if $\beta$-carotene affects the enzymatic activation of CPA, we would expect to find a reduction in the frequency of chromosome damage induced by CPA which was found in these above studies. Nevertheless, Renner (1985), using CPA, reported no anticlastogenic activity of $\beta$-carotene in Chinese hamster bone marrow cells for induction of chromosomal aberrations. He also showed that $\beta$-carotene exhibited anticlastogenic effects on aberrations induced only by direct-acting mutagens thio-TEPA, methyl methanesulfonate and busulfan. Apparent differences between these results and those obtained by Abraham et al. (1986) and Darroudi et al. (1988) could be due to the use of $\beta$-carotene in one case, and carrot juice in 
the other, as well as the different species and route of administration of CPA.

On the other hand, the results obtained by Renner (1985) using $\beta$-carotene doses above 100 $\mathrm{mg} / \mathrm{kg}$ agree, in part, with our results. We also did not observe a statistically significant decrease in the frequency of aberrant metaphases to the 2 higher $\beta$-carotene concentrations (100 and 200 $\mathrm{mg} / \mathrm{kg}$ ) tested.

In the present study the anticlastogenic activity of $\beta$-carotene was better detected when the cells were fixed $32 \mathrm{~h}$ after CPA treatment, although a tendency in reducing the CPA clastogenicity was already observed at 16 and $24 \mathrm{~h}$. This may be due to a longer time for activity of $\beta$-carotene on CPA and its metabolites and, over time, on lower CPA concentrations. The frequency of aberrant metaphases induced by CPA is normally lower when analysed $32 \mathrm{~h}$ after exposure in comparison to earlier fixation times. This could be due to the death of affected cells; however, that continuous action of metabolites of CPA (in lower concentrations produced already through interactions with some biological molecules) is still able to induce chromosomal aberrations cannot be ruled out. Since the cells scored at different sampling times may represent cells at different stages of the cell cycle at the time of treatment, and since there exists differential stage sensitivity to treatment with chemical mutagens, at least part of the differences in effects found at different fixation times can be attributed to this phenomenon.

Another mechanism of antimutagenesis proposed for $\beta$-carotene is through its antioxidant and free-radical scavenging activity (Burton and Ingold, 1984; Krinsky, 1989; De Flora, 1990). In general, the antioxidants are expected to inhibit mutagenesis at some levels as deactivating mutagens by chemical reaction and blocking reactive molecules through scavenging reactive oxygen species (De Flora and Ramel, 1988). Recently, Renner (1984) using the antioxidant agent, ethoxyquin, and Kola et al. (1989) using ascorbic acid reported a protective effect of these antioxidants on CPA-induced chromosomal aberrations.

The absence of a dose-response relationship observed in our data can be due to $\beta$-carotene acting by different mechanisms at various concentration levels. According to De Flora and Ramel
(1988), prevention of mutagenesis may be achieved at the metabolic stage either by inhibiting those biochemical mechanisms which are responsible for the activation of promutagens to electrophilic metabolites, or by stimulating the enzymatic detoxification of chemicals, or, since the mechanisms are quite often competitively or sequentially involved, by shifting their balance in favour of detoxification. Thus, for each $\beta$-carotene concentration tested, this balance might have been altered.

\section{Acknowledgements}

The authors are grateful to Prof. A.T. Natarajan for comments on the manuscript, and to Miss Ana Rita Silva, Silvia Lima Costa and Rosimery Santos Arbués for their technical assistance. This investigation was supported by grants from Fundação de Amparo à Pesquisa do Estado de São Paulo (FAPESP), Conselho Nacional de Desenvolvimento Científico e Tecnológico (CNPq), Financiadora de Estudos e Projetos (FINEP), Comissão Interinstitucional de Ciência e Tecnologia do Estado da Bahia (COMCITEC) and ROCHE.

\section{References}

Abraham, S.K., S. Mahajan and P.C. Kesavan (1986) Inhibitory effects of dietary vegetables on the in vivo clastogenicity of cyclophosphamide, Mutation Res., 172, 51-54.

Basu, T.K., N.J. Temple and J. Ng (1987) Effect of dietary $\boldsymbol{\beta}$-carotene on hepatic drug-metabolizing enzymes in mice, J. Clin. Biochem. Nutr., 3, 95-102.

Belisario, M.A., R. Pecce, C. Battista, N. Panza and G. Pacilio (1985) Inhibition of cyclophosphamide mutagenicity by $\beta$-carotene, Biomed. Pharmacother., 39, 445-448.

Burton, G.W., and K.U. Ingold (1984) $\beta$-Carotene: an unusual type of lipid antioxidant, Science, 224, 569-573.

Cohen, J.L., and J.Y. Jao (1970) Enzymatic bases of cyclophosphamide activation by hepatic microsomes of the rat, J. Pharmacol. Exp. Ther., 174, 206-210.

Darroudi, F., H. Targa and A.T. Natarajan (1988) Influence of dietary carrot on cytostatic drug activity of cyclophosphamide and its main directly acting metabolite: Induction of sister-chromatid exchanges in normal human lymphocytes, Chinese hamster ovary cells, and their DNA repairdeficient cell lines, Mutation Res., 198, 327-335.

De Flora, S. (1990) Mechanisms of inhibitors of genotoxicity: Relevance in preventive medicine, in: M.L. Mendelsohn and R.J. Albertini (Eds.), Mutation and Environment, Environmental Genotoxicity Risk and Modulation, Part E, Wiley-Liss, New York, pp. 307-318. 
De Flora, S., and S. Ramel (1988) Mechanisms of inhibitors of mutagenesis and carcinogenesis, Classification and overview, Mutation Res., 202, 285-306.

Domeyer, B.E., and N.E. Sladek (1980) Kinetics of cyclophosphamide biotransformation "in vivo", Cancer Res., 40, 174-180.

Hsu, T.C., and J.L. Patton (1969) Bone marrow preparations for chromosome studies, in: K. Bernischke (Ed.), Comparative Mammalian Cytogenetics, Springer-Verlag, pp. 454460.

Kola, I., R. Vogel and H. Spielmann (1989) Co-administration of ascorbic acid with cyclophosphamide (CPA) to pregnant mice inhibits the clastogenic activity of CPA in preimplantation murine blastocysts, Mutagenesis, 4, 297-301.

Krinsky, N.I. (1989) Carotenoids and cancer in animal models, J. Nutr., 119, 123-126.

Krinsky, N.I., and S.M. Deneke (1982) Interaction of oxygen and oxi-radicals with carotenoids, J. Natl. Cancer Inst., 69, 205-209.

Manoharan, K., and M.R. Banerjee (1985) $\beta$-Carotene reduces sister chromatid exchanges induced by chemical carcinogens in mouse mammary cells in organ culture, Cell Biol. Int. Rep., 9, 783-789.

Mohn, G.R., and J. Ellenberger (1976) Genetic effects of cyclophosphamide, ifosfamide and trofosfamide, Mutation Res., 32, 331-360.

Moon, R.C., and L.M. Itri (1984) Retinoids and cancer, in: M. P. Sporn, A.B. Roberts, and D.S. Goodmam (Eds.), The Retinoids, Vol. 2, Academic Press, New York, pp. 327-371.
Pereira, C.A.B. (1991) Testes estatísticos para comparar proporções em problemas de citogenética, in: M.N. RabelloGay, M.A. La Regina Rodrigues and R. Monteleone Neto (Eds.), Mutagênese, Carcinogênese e Teratogênese: Métodos e Critérios de Avaliação, Revista Brasileira de Genética, Ribeirão Preto, SP, in press.

Peto, R., R. Doll, J.D. Buckley and M.B. Sporn (1981) Can dietary beta-carotene naturally reduce human cancer rates? Nature (London), 290, 201-208.

Raj, A.S., and M. Katz (1985) $\boldsymbol{\beta}$-Carotene as an inhibitor of benzo( $a$ )pyrene and mitomycin $\mathrm{C}$ induced chromosomal breaks in the bone marrow of mice, Can. J. Genet. Cytol., 27, 598-602.

Renner, H.W. (1984) Antimutagenic effect of an antioxidant in mammals, Mutation Res., 135, 125-129.

Renner, H.W. (1985) Anticlastogenic effect of $\beta$-carotene in Chinese hamsters. Time and dose response studies with different mutagens, Mutation Res., 144, 251-256.

Stich, H.F., and B.P. Dunn (1986) Relationship between cellular level of beta carotene and sensitivity to genotoxic agents, Int. J. Cancer, 38, 713-717.

Wald, N. (1987) Retinol, beta-carotene and cancer, Cancer Sur., 6, 635-651.

Ziegler, R.G. (1989) A review of epidemiologic evidence that carotenoids reduce the risk of cancer, J. Nutr., 119, 116122. 